\title{
Fate and turnover rate of ovarian follicular cysts in dairy cattle*
}

\author{
D. L. Cook $\uparrow$, C. A. Smith $\ddagger$, J. R. Parfet $\dagger$, R. S. Youngquist $\ddagger$, \\ E. M. Brown§ and H. A. Garverick $\uparrow$ \\ Departments of $\dagger$ Dairy Science, $\$$ Veterinary Medicine and Surgery, and \\ §Veterinary Biomedical Sciences, University of Missouri-Columbia, Columbia, MO 65211, USA
}

\begin{abstract}
Summary. Non-lactating, multiparous dairy cows diagnosed as having cysts by palpation per rectum were used. Cysts were induced with oestradiol-17 $\beta$ (15 mg) and progesterone $(37.5 \mathrm{mg}$ ) dissolved in ethanol and injected s.c. twice daily for 7 days. Following initial diagnosis of cysts, ovaries were exposed by midventral laparotomy, and the perimeter of the base of each cyst was marked with subepithelial injections of charcoal. Ovaries were removed from cows by transvaginal incision at 10 days (Group $1 ; \mathbf{N}=8$ ), 20 days (Group 2; $\mathbf{N}=8$ ), or 40 days (Group 3; $N=7$ ) after marking of cysts. Ovaries were examined for structures present and their relationship to the marked site. Corpora lutea with ovulation papilla were present in $7 / 23$ cows $(1 / 8,4 / 8$ and $2 / 7$, for Groups 1,2 and 3, respectively). In these 7 cows, corpora lutea were at a site different from the original structure that was marked. Marked structures persisted for the duration of the experimental period in 1 and 2 cows, in Groups 1 and 3, respectively. In the remaining 13 cows, new large follicular structures (cysts) were present at a site other than that marked with charcoal. These structures developed on the ovary contralateral to the one originally marked in 9 of 13 cows. Cysts are therefore dynamic in nature and may persist or may be replaced by others.
\end{abstract}

Keywords: ovary; follicular cysts; turnover rate; dairy cattle

\section{Introduction}

It has been well established that ovarian follicular cysts (cysts) are anovulatory structures which arise from follicles. Previous work has suggested that the original cyst persists as long as the symptoms are apparent. This assumption is contrary to our knowledge of the rapid turnover of follicles (Dufour et al., 1972; Matton et al., 1981; Sirois \& Fortune, 1988; Savio et al., 1988) and the occurrence of many follicles at all stages of development and atresia in ovaries at slaughter (Choudary et al., 1968; Marion et al., 1968). Kesler et al. (1980) suggested that ovarian cysts possibly regress, usually in the presence of other follicular structures which subsequently develop into additional cysts. Also, high variability of peripheral concentrations of luteinizing hormone (LH), oestradiol-17 $\beta$ and progesterone in cows with cysts (Cantley et al., 1975; Garverick et al., 1976; Kesler et al., 1978) indicates the possibility of structural and functional changes occurring at the ovarian level.

Histopathological studies indicate that cysts possess morphological similarities to atretic follicles (Garm, 1949; Marion et al., 1968). Cysts in cattle have various degrees of thinning and degeneration of the thecal and granulosa cells (Garm, 1949; Yamauchi \& Inui, 1954; Short, 1962; Marion

\footnotetext{
*Reprint requests to Dr H. A. Garverick.

-Present address: IVY Laboratories, 8857 Bond Street, Overland Park, KS 66214, USA.

¥Present address: Department of Food Animal \& Equine Medicine, School of Veterinary Medicine, North Carolina State University, 4700 Hillsboro Street, Raleigh, NC 27606, USA.
} 
et al., 1968; Al-Dahash \& David, 1977; Brown et al., 1982). In addition, some cysts spontaneously luteinize or luteinize after GnRH-induced LH release. The increased thickness of luteinized cyst walls is due to proliferation of luteal cells apparently of theca interna origin (Brown et al., 1982).

The development of cysts has been induced in cows by injections of oestradiol-17 $\beta$ and progesterone (Erb et al., 1973; Winters et al., 1986). The present study was conducted to determine the lifespan, fate and turnover rate of induced cysts in cattle and to correlate steroid secretion and histological changes to the above characteristics.

\section{Materials and Methods}

Animals. Non-lactating multiparous dairy cows diagnosed as having cysts were used. The 23 cows were at least 200 days post partum and exhibiting clinically normal oestrous cycles. Cysts were induced with twice daily s.c. injections of $15 \mathrm{mg}$ oestradiol-17ß (Sigma Chemical, St Louis, MO, USA) and $37.5 \mathrm{mg}$ progesterone (Sigma) for 7 days beginning on Day 15 of the oestrous cycle. Classically, diagnosis of cysts has been based upon the finding via palpation per rectum of a follicular structure(s) of $2.5 \mathrm{~cm}$ in diameter or greater that is present for 10 days in the absence of a corpus luteum. Kesler et al. (1980) reported that some untreated cysts appeared to regress in size and were replaced by others. In the present study, cysts were defined as the presence of follicular structures (which may or may not have been the same structure) of $2.0 \mathrm{~cm}$ or greater in diameter that were present for 10 days without occurrence of ovulation and corpus luteum (CL) development. Estimation of ovarian structures was based on thrice weekly examinations by palpation per rectum. Following initial diagnosis of cysts, ovaries were examined by mid-ventral laparotomy and cysts were marked around their periphery with subepithelial injections of charcoal. At the time of cyst marking, laparoscopic examination of both ovaries was made. A gross description of the location of observed structures was recorded and photographs were taken. Ovaries were not palpated per rectum after cyst marking before ovariectomy.

Ovarian removal and examination. Ovaries were removed from cows by transvaginal incision at 10 days (Group 1 ; $\mathrm{N}=8$ ), 20 days (Group 2; $\mathrm{N}=8$ ) or 40 days (Group 3; $\mathrm{N}=7$ ) after marking of cysts. At this time ovaries were examined to determine the structures present and their relationship to the marked cyst. The appearance of the previously marked cyst was recorded. Ovaries were then fixed in mercuric formal solution for 3 days followed by washing in running water for $24 \mathrm{~h}$. Several tissue blocks were sectioned through various planes of each ovary, dehydrated in tetrahydrofuran, vacuum-infiltrated and embedded in paraplast (Brown et al., 1982). Sections, $6 \mu \mathrm{m}$ in thickness, were cut from each block and stained with haematoxylin and eosin as well as Movat's modified pentachrome stain (Priedkalns et al., 1968). Microscopic examination was used to characterize the functional state of the granulosa and thecal cells as well as thickness and whether or not the luteinization was present within the layers.

Blood sampling schedule. From the day that cysts were marked until the day of ovariectomy, 3 blood samples were collected daily at $15-\mathrm{min}$ intervals by venepuncture. Also, samples were collected by indwelling jugular cannulas every $15 \mathrm{~min}$ for $6 \mathrm{~h}$ on a twice weekly basis. Blood samples were kept on ice and taken to the laboratory and stored for $12 \mathrm{~h}$ at $4^{\circ} \mathrm{C}$. Samples were then centrifuged at $1500 \mathrm{~g}$ for $30 \mathrm{~min}$, and the serum was harvested and stored at $-20^{\circ} \mathrm{C}$ until concentration of hormones was determined.

Hormone analyses. Serum concentrations of $\mathrm{LH}$ and follicle-stimulating hormone (FSH) were measured by heterologous double-antibody radioimmunoassay as described by Zaied et al. (1980) and Garverick et al. (1988), respectively. The intra- and inter-assay coefficients of variation were $11.7 \%$ and $7.9 \%$, respectively, for $\mathrm{LH}$ and $9.5 \%$ and $7.9 \%$ respectively for FSH. Serum and follicular fluid concentrations of progesterone (Cantley et al., 1975; Hernandez-Ledezma et al., 1982, respectively) were measured by radioimmunoassay. The inter- and intra-assay coefficients of variation for progesterone were $22 \cdot 4 \%$ and $15 \cdot 7 \%$ respectively. Sensitivities of the assays were $0 \cdot 1 \mathrm{ng}$ $\mathrm{LH} /$ tube, $2.0 \mathrm{ng} \mathrm{FSH} /$ tube and $0.05 \mathrm{ng}$ progesterone/tube.

A magnetic solid-phase assay for oestradiol-17 $\beta$ was obtained from Serono Diagnostics (Norvell, MA, USA) and validated for follicular fluid and serum. Follicular fluid (unextracted) was diluted with assay buffer (PBS containing $1 \%$ gelatin) to a factor of 100 - or 1000 -fold before hormone determination. Oestradiol- $17 \beta$ was removed from serum with diethyl ether. Lyophilized ${ }^{125}$ I-labelled oestradiol- $17 \beta$ was reconstituted with $12 \mathrm{ml} 0.05$ M-ethylenediaminetetraacetate (EDTA) containing phosphate-saline buffer and $0 \cdot 1 \%$ gelatin (PBS-gel-EDTA). Oestradiol-17 $\beta$ standards $(2 \cdot 5-100 \mathrm{pg})$ were prepared in assay buffer containing PBS-gel-EDTA.

A robotic sample processor (Tecan U.S., Chapel Hill, NC, USA) was programmed to add the following reagents: $25 \mu \mathrm{l}$ antiserum against rabbit oestradiol-17 $\beta$ were added to standard or unknown samples for a total volume of $0.35 \mathrm{ml}$. Assay tubes were mixed and incubated for $30 \mathrm{~min}$ at room temperature. Following the first incubation, $0.025 \mathrm{ml}{ }^{125} \mathrm{I}$-labelled oestradiol-17 $\beta$ was added and the tubes allowed to incubate for additional $90 \mathrm{~min}$ at room temperature. After the second incubation, $0.25 \mathrm{ml}$ sheep anti-rabbit gamma globulin bonded to a magnetic particle was added, and the tubes were incubated for $10 \mathrm{~min}$ at room temperature. Following the final incubation, assay tubes were loaded into the MAIA rack and separator (Ciba-Corning, Medfield, MA, USA) and allowed to separate for $10 \mathrm{~min}$ at room temperature. The supernatant was decanted and radioactivity bound to the solid phase was determined on a Beckman Gamma Spectrophotometer (Beckman Instruments, Fullerton, CA, USA). 
Specific binding was plotted (logit transformation) against log dose of oestradiol-17 (Sigma). Parallelism was demonstrated $(r=0.97)$ with increasing volumes of serum $(0.025,0.05,0.01$ and $0.2 \mathrm{ml})$. When $1 \mathrm{ng}$ oestradiol-17 $\beta$ was added to $0.025,0.05,0.1$ and $0.2 \mathrm{ml}$ of serum, it was quantitatively recovered $(\geq 100 \%)$. Parallelism $(r=0.97)$ and quantitative recovery $(\geq 100 \%)$ of oestradiol $-17 \beta$ in follicular fluid were demonstrated with increasing amount of oestradiol- $17 \beta(10,5,2.5$ and $0.5 \mathrm{pg})$ added to follicular fluid from which steroids had been removed by charcoal. Sensitivity of individual assays was determined by calculating an overall mean and one standard deviation of the $v$-intercepts and averaged $1 \cdot 2 \pm 0 \cdot 2 \mathrm{pg} /$ tube ( $n=6$ assays). Inter- and intra-assay coefficients of variation for oestradiol- $17 \beta$ were $2.9 \%$ and $5.9 \%$, respectively.

Statistical analysis. Mean concentrations of LH and FSH for individual cows were calculated for each 6-h period. Hormone pulse frequency (pulses/6 h), amplitude ( $\mathrm{ng} / \mathrm{pulse}$ ) and duration $(\mathrm{min} / \mathrm{pulse})$ for individual cows were calculated by computer algorithm methods for each sampling period. The following criteria were used to define a hormone pulse: (1) an increase greater than or equal to one standard deviation of the concentration of hormone for each sampling period above the preceding nadir value; (2) the ascending side of the peak could not contain more than one point between the nadir and peak value; and (3) the peak must be accompanied by at least two other consecutive decreasing hormone concentrations. Frequency of pulses for individual cows was calculated as the sum of all pulses detected during each sampling period. Square root transformation was used before statistical analysis to achieve homogeneity of variance for number of hormone pulses. Amplitude of hormone pulses was the mean height of all pulses detected in each sampling period. Duration of hormone pulses was calculated as the average time interval for all peaks detected during each 6 -h period.

The time of ovulation for cows which ovulated was estimated by the subsequent rise in daily concentrations of progesterone which peaked above $2.5 \mathrm{ng} / \mathrm{ml}$. Samples obtained from cows after the estimated day of ovulation were excluded from further analysis.

Data were analysed using Statistical Analysis Systems (SAS). The endocrine data were analysed using a factorial split-plot in time analysis of variance for repeated measures (Gill \& Hafs, 1971). Ovulation, turnover or persistence of cystic condition, day and cow were the main effects with $\mathrm{LH}, \mathrm{FSH}$, oestradiol-17 $\beta$ and progesterone concentrations as well as LH and FSH pulse parameters (amplitude, frequency and duration) being the dependent variables. The effect of cow within response was used as the error term for testing effect of treatment. A $\chi^{2}$ analysis was used on proportional data (Snedecor \& Cochran, 1980).

\section{Results}

\section{Ovarian parameters}

At ovariectomy, three different ovarian responses were observed, and each occurrence was evident at each time period (Days 10,20 or 40 after cyst marking; Table 1). The first observation was defined as turnover $(\mathrm{N}=13 / 23)$. Marked cysts were absent or greatly reduced in size and a new large follicular structure (cyst) had developed at another site on the same $(N=4)$ or contralateral $(N=9)$ ovary (Fig. 1).

Table 1. Turnover rate of ovarian follicular cysts in dairy cattle at 10 , 20 or 40 days after charcoal marking of cysts

\begin{tabular}{lcrccc}
\hline & \multirow{2}{*}{$\begin{array}{c}\text { Day after } \\
\text { marking }\end{array}$} & $\mathrm{N}$ & & \multicolumn{3}{c}{ Response } \\
\cline { 5 - 6 } Group & 10 & 8 & $1 / 8$ & $6 / 8$ & $1 / 8$ \\
\hline 1 & 20 & 8 & $4 / 8$ & $4 / 8$ & $0 / 8$ \\
2 & 40 & 7 & $2 / 7$ & $3 / 7$ & $2 / 7$ \\
3 & & 23 & $7 / 23^{\mathrm{a}}$ & $13 / 23^{\mathrm{b}}$ & $3 / 23^{\mathrm{c}}$ \\
Total & & &
\end{tabular}

a,b,c Proportions with different superscripts differ $(P<0 \cdot 01)$.

Secondly, resumption of cyclic ovarian activity occurred in some cows $(N=7 / 23)$, which was determined when corpora lutea, complete with ovulation papilla, were present on either ovary at ovariectomy and the previously marked cyst was decreased in size and/or devoid of follicular fluid (Fig. 2). Corpora lutea were observed in these 7 cows at a site different from those which were marked on the same $(N=3)$ or contralateral $(N=4)$ ovary. None of the cyst(s) originally marked ovulated. 

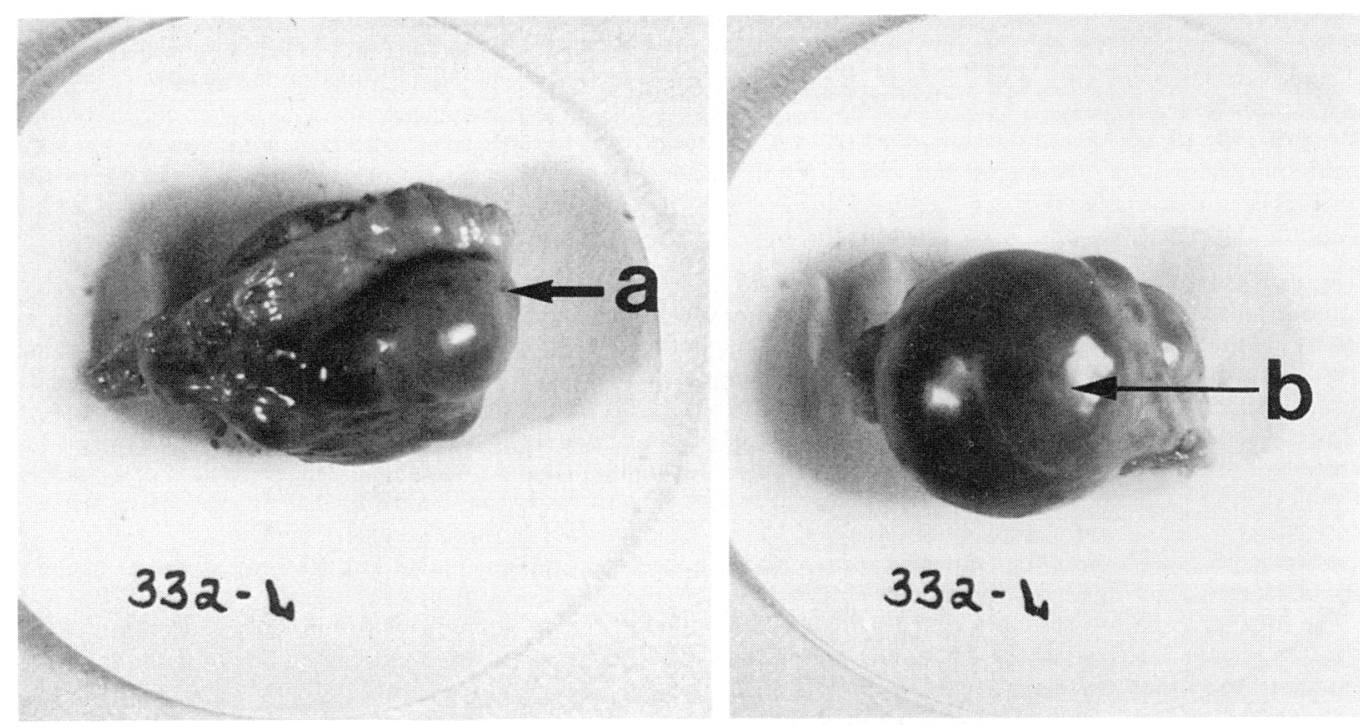

Fig. 1. An ovary from a cow which exhibited turnover with the previously marked cyst (a) which had regressed in size. The new cystic structure (b) is on the opposite side of the same ovary.

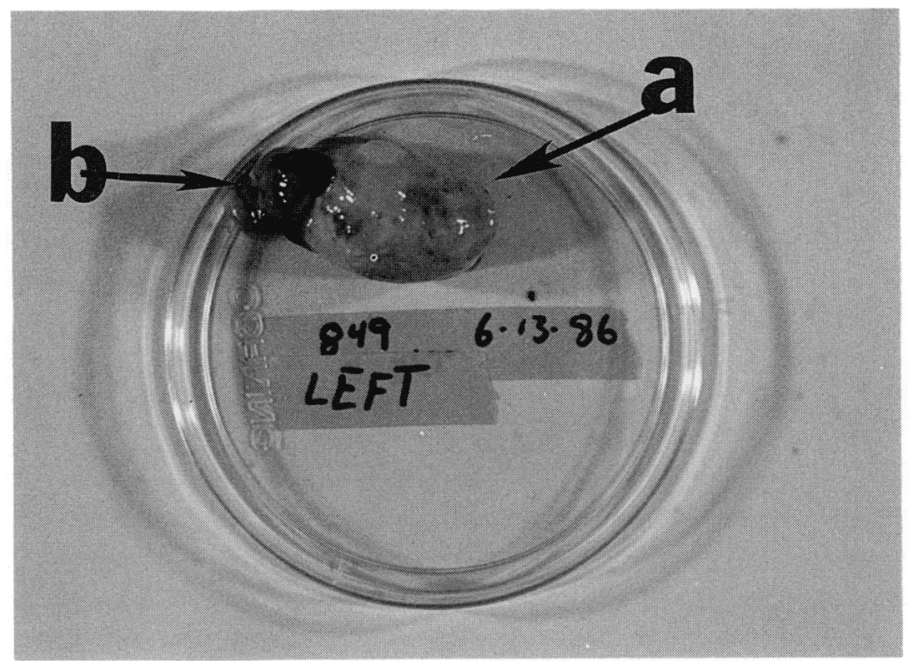

Fig. 2. An ovary from a cow which displayed spontaneous recovery showing the previously marked cyst (a) and the corpus luteum with ovulation papilla (b).

Cysts persisted in the remaining 3 cows (Fig. 3). The cyst which was marked was still present at time of ovariectomy at a similar or greater size than when marked. One of these cows had 3 small follicles $(<10 \mathrm{~mm})$ which accompanied the larger cystic structure, and the other 2 cows had 1 medium sized $(10-20 \mathrm{~mm})$ follicle which was adjacent to the cyst. In these 3 cows, the ovaries contralateral to the one containing the cyst had only 1 or 2 small follicles present at the time of ovariectomy. There is the possibility that another cyst may have arisen very near the site of the original cyst in cows with persistent cysts. It was more probable, however, that the original cyst 


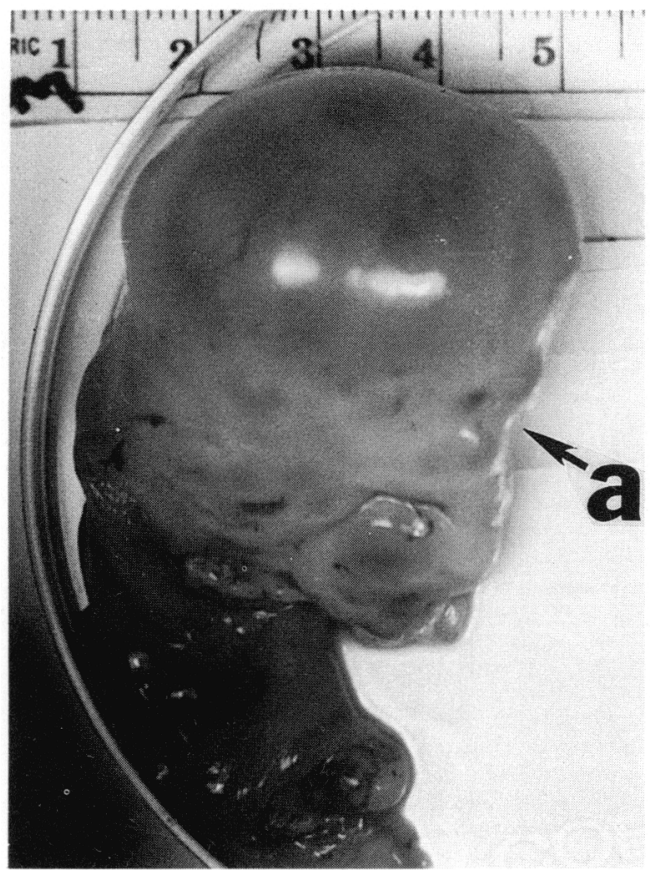

Fig. 3. An ovary from a cow which exhibited persistence with the cystic structure surrounded with charcoal marks (a).

persisted since charcoal markings remained symmetrically located around the base of the structures (2) or around the lower portion of the antrum in the one cyst which increased in size.

The number of cows that exhibited turnover of cysts was greater $(P<0.01)$ than the number with spontaneous recovery or persistent cysts. Spontaneous recovery occurred in a greater $(P<0.01)$ proportion of cows than those with persistent cysts. Occurrence of responses did not differ among time periods.

\section{Histology}

Cysts present at ovariectomy were grouped into three categories based upon histological classification $(n=16)$. One group of cysts $(n=6$; Fig. 4) had evidence of luteinization in the thecal layers. The granulosa cells of these follicles were small, pycnotic and displayed chromatolysis (degenerating). In some areas, they were pulled away from the basal lamina. The marked cyst of one cow in which the cyst had persisted for 10 days was included in this group. The second group of cysts appeard to be in the early stages of cystic atresia $(n=4$; Fig. 4$)$. The granulosa cell layer in these cysts was thin and the few remaining cells were small and pycnotic. The follicular lumen contained cellular debris. The thecal cells appeared secretory, but not luteinized. While these follicular structures resembled atretic follicles in several respects, they were much larger $(2 \cdot 7-5 \cdot 4 \mathrm{~cm}$ diameter) than those observed in cows exhibiting normal oestrous cycles and did not exhibit granulosa cell layer infolding. The marked cysts from the 2 cows that persisted for 40 days were included in this group. In the third type of cyst, the cystic atresia was characterized by degenerating and fragmented granulosa cells. The thecal layers contained fibrous connective tissue, but there was no evidence of luteinization.

The areas originally occupied by the charcoal-marked cysts were also examined. In 17 ovaries this area was filled with highly coiled, thick-walled blood vessels embedded in small patches of connective tissue similar to that seen in developing corpora albicantia or regressing corpora lutea. 


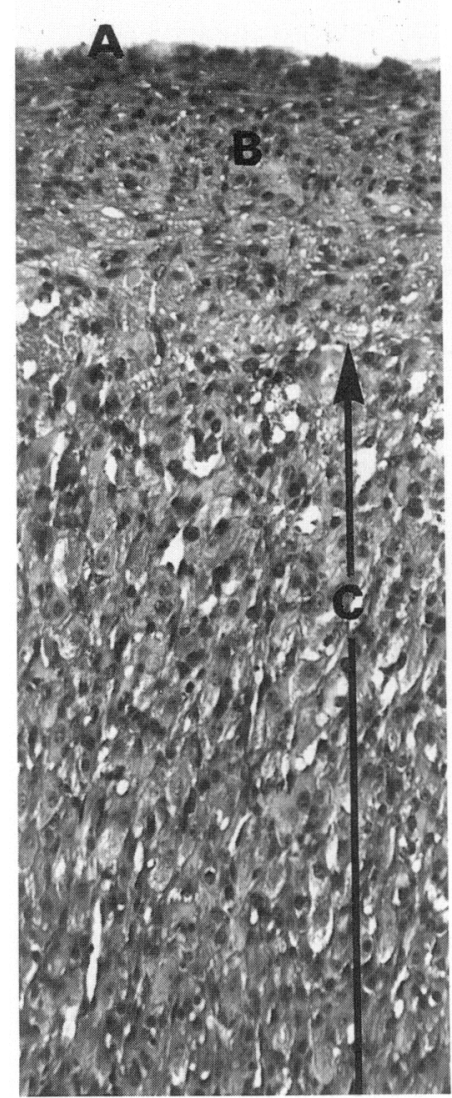

(a)

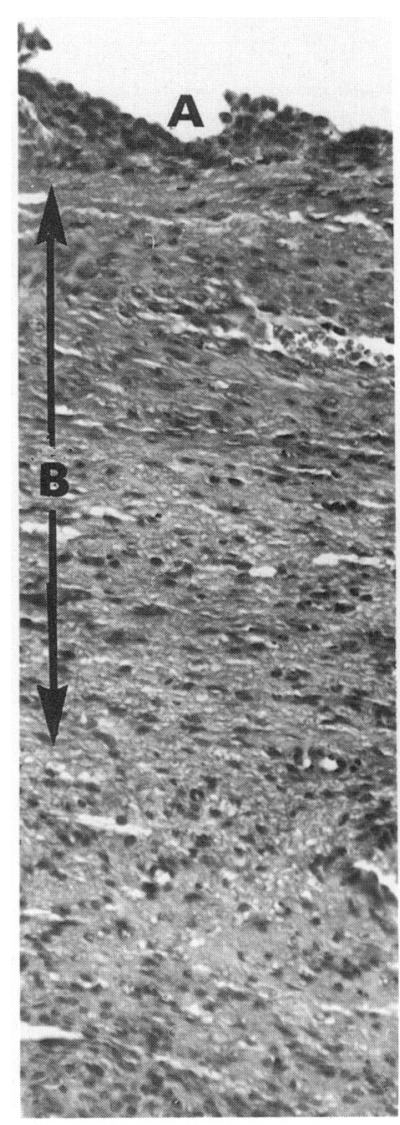

(b)

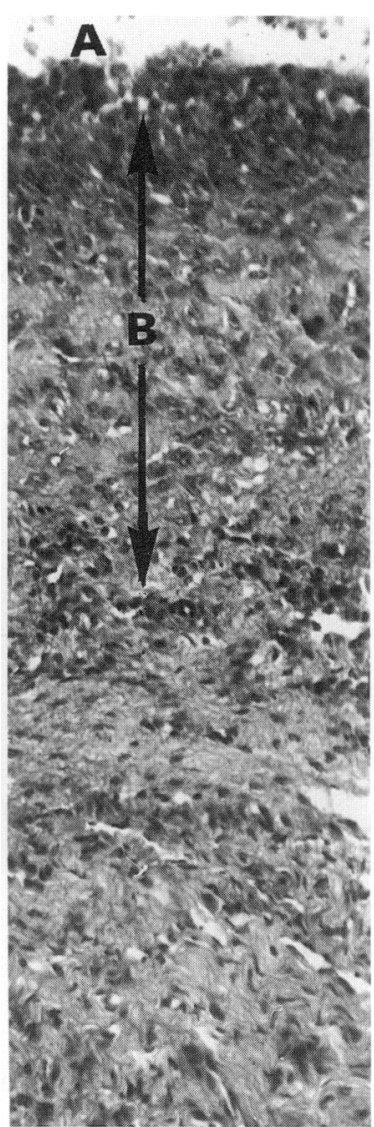

(c)

Fig. 4. Sections through (a) a luteinized cyst, (b) an atretic cyst and (c) a fibrotic cyst. In (a) the granulosa cells (A) are degenerated. The innermost part of the thecal layers (B) is mostly connective tissue and the remainder $(\mathrm{C})$ is composed of luteal cells. In (b) the granulosa cells (A) are degenerating and separating from the basal lamina. The thecal layers (B) are normal connective tissue. In (c) the granulosa cells (A) are mostly sloughed and the thecal layers (B) contain thick collagenous fibres. Movat stain, $\times 165$.

The remaining ovaries $(n=6 / 23$ ) had a small patch of luteal tissue within the confines of the charcoal circles.

\section{Hormone concentrations}

When concentrations of oestradiol-17 $\beta$ and progesterone in follicular fluid from the three different histological cyst types were compared, a great deal of variance was observed within each cyst type (Table 2). However, the follicular fluid from those cysts with luteinized thecal layers had higher $(P<0.01)$ concentrations of progesterone than did that from cysts which resembled atretic follicles. Follicular fluid from cysts with connective tissue within the thecal layers had progesterone levels similar to the fluid from the other two cyst types. Concentrations of oestradiol-17 $\beta$ in follicular fluid did not differ among the three cyst types and were highly variable within each cyst type. Cows which spontaneously recovered had serum concentrations of progesterone in excess of 
$\mathrm{l} \mathrm{ng} / \mathrm{ml}$ for a period of 6-15 days (mean 6.6 days) and serum concentration of progesterone exceeded $3 \mathrm{ng} / \mathrm{ml}$ by $8-18$ days (mean 13.8 days) after cyst marking. Therefore, the average time of ovulation after cyst marking appeared to be from 5 to 14 days.

Table 2. Follicular fluid concentrations ( $\mathrm{ng} / \mathrm{ml})$ of oestradiol$17 \beta$ and progesterone for the three histological types of ovarian follicular cysts

\begin{tabular}{lcrc}
\hline Cyst type & N & Oestradiol & Progesterone \\
\hline Luteinized theca & 6 & $349 \pm 157$ & $3497 \pm 915^{\mathrm{a}}$ \\
Large atretic follicles & 4 & $84 \pm 49$ & $718 \pm 339^{\mathrm{b}}$ \\
Connective tissue in theca & 6 & $187 \pm 34$ & $941 \pm 295^{\mathrm{a}, \mathrm{b}}$ \\
\hline
\end{tabular}

${ }^{a, b}$ Means $( \pm$ s.e.m.) with different superscripts within the column differ $(P<0 \cdot 01)$.

Table 3. Comparison of LH and FSH secretory patterns during the period after marking for cows with follicles which remained cystic $(\mathrm{N}=16)$ and cows which spontaneously recovered $(\mathrm{N}=7)$

\begin{tabular}{|c|c|c|c|}
\hline & & \multicolumn{2}{|c|}{ Response } \\
\hline & & $\begin{array}{l}\text { Remained } \\
\text { cystic } \\
(N=16)\end{array}$ & $\begin{array}{c}\text { Spontaneously } \\
\text { recovered } \\
(\mathrm{N}=7)\end{array}$ \\
\hline \multirow[t]{4}{*}{$\mathrm{LH}$} & Mean conc. $(\mathrm{ng} / \mathrm{ml})$ & $1.9 \pm 0.1$ & $1 \cdot 1 \pm 0 \cdot 1$ \\
\hline & Amplitude (ng/ml) & $1.8 \pm 0.2$ & $1 \cdot 1 \pm 0 \cdot 2$ \\
\hline & Frequency (pulses $/ 6 \mathrm{~h}$ ) & $3.5 \pm 0.1$ & $2.8 \pm 0.4$ \\
\hline & Duration (min) & $73.2 \pm 1 \cdot 1$ & $77.5 \pm 9.5$ \\
\hline \multirow[t]{4}{*}{ FSH } & Mean conc. ( $\mathrm{ng} / \mathrm{ml})$ & $6.6 \pm 0.3$ & $9.5 \pm 0.9$ \\
\hline & Amplitude (ng/ml) & $2.9 \pm 0.2$ & $4 \cdot 3 \pm 0.5$ \\
\hline & Frequency (pulses $/ 6 \mathrm{~h}$ ) & $2.8 \pm 0.1$ & $2.5 \pm 0.3$ \\
\hline & Duration (min) & $80.7 \pm 1.7$ & $89 \cdot 0 \pm 5 \cdot 4$ \\
\hline
\end{tabular}

Values are mean \pm s.e.m.

No differences were observed between hormone responses, and the two groups were combined to compare the values for cows that remained cystic $(N=16)$ or ovulated $(N=7)$. As shown in Table 3, although mean concentrations of the gonadotrophins fluctuated throughout the period after marking, there were no differences in mean values between cows that ovulated and those that remained cystic. There also were no differences detected in any of the pulse parameters for LH or FSH between the two groups of cows. Accurate comparison of these endocrine parameters was difficult to assess because of the variability in and determination of the timing of cyst turnover among cows.

Mean concentrations of progesterone in serum remained low $(<2.0 \mathrm{ng} / \mathrm{ml})$ for cows exhibiting both responses until ovariectomy or ovulation occurred. However, most individuals displaying either response (10/16 and $7 / 7$ for cows remaining cystic or ovulating, respectively) exhibited daily fluctuations in concentration of progesterone with mean levels exceeding $0.5 \mathrm{ng} / \mathrm{ml}$ for several days before declining (mean $0.23 \mathrm{ng} / \mathrm{ml}$ ). 


\section{Discussion}

Nearly all of our knowledge of ovarian cysts has been based upon diagnosis made by palpation per rectum. Because of the classical definition of cysts, we felt it was necessary in the present study to observe follicular structures in the absence of ovulation for 10 days before marking cysts. It is possible that some cysts did turnover from the time of first diagnosis to marking of cysts. However, more than one examination is often necessary to be certain that the palpated structure is an anovulatory follicle rather than a preovulatory follicle or developing corpus luteum.

Earlier work from this laboratory and others assumed that cysts persisted for considerable periods of time if left untreated. However, the present observations suggest that most of the steroidinduced cysts were not static structures. Most cysts were characterized by turnover whereby the original cyst regressed, and a new follicular structure (cyst) developed at a different site on the same or contralateral ovary. The turnover of cysts was accompanied by variable concentrations of steroids and gonadotrophins in serum. In some cows, the cystic structure apparently luteinized, as evidenced by increased progesterone in serum, before regressing in size. Kesler et al. (1980) reported similar variations in endocrine parameters of cows with spontaneously occurring cysts during a 30-day observation period. Based upon estimation of ovarian structures by rectal palpations, they suggested that cysts appeared to regress in some cows and were replaced by other follicular structures.

The observation of follicular turnover is not unique to cows with cysts. Marion et al., (1968) reported that when follicles became atretic their lifespan is nearly complete. Several studies have proposed that the oestrous cycle of cattle is characterized by growth of 2 (Rajakowski, 1960; Swanson et al., 1972; Pierson \& Ginther, 1987) or 3 (Choudary et al., 1968; Marion et al., 1968; Dufour et al., 1972; Matton et al., 1981; Ireland, 1987) waves of follicles. The use of ultrasonography has shown that 3 dominant follicles usually appear during the bovine oestrous cycle (Savio et al., 1988; Sirois \& Fortune, 1988). The turnover rate appears to be 7-10 days. Whether follicular growth occurs in distinct waves or is a continuous process is still unclear. Nevertheless, follicular size decreases near the end of the life of a follicle. This phenomenon was also observed for cysts in this study. Cysts usually decreased in size and often did not contain follicular fluid when observed following removal of ovaries at 10,20 or 40 days after marking.

While the exact amount of time required for turnover of cysts could not be determined in this study, turnover was observed in some cows (6/10) in which ovaries were removed 10 days after marking of the cyst. Also, cows which displayed turnover of cysts had at least one increase in serum concentration of oestradiol-17 $\beta$ every 10 days which was followed by an increase in serum concentration of progesterone 3.5 days later. Whether or not the turnover rate of cysts in this study is similar to that of follicles in heifers exhibiting normal oestrous cycles is unknown.

Some cows $(20 \%)$ with spontaneously occurring cysts recover without treatment by initiating ovulatory ovarian cycles (Bierschwal et al., 1975; Kesler \& Garverick, 1982). The proportion of spontaneous recovery in cows with steroid-induced cysts in this study (7/23) is similar to the previous reports of recovery from naturally occurring cysts (Bierschwal et al., 1975). In this study, why certain cows recover without treatment and others do not is not clear from examining the endocrine parameters, possibly because we were unable to discern the exact time of turnover. Similarly, it is difficult to explain why cysts persisted in $3 / 23$ cows for as long as 40 days.

Another finding of this study was that all cysts were anovulatory. In every case of spontaneous recovery, the site of ovulation was at a site different from the original marked cyst, on the opposite ovary or at another site on the same ovary. Kesler et al. (1981) have reported that cysts were anovulatory after exposure to a GnRH-induced LH surge. Cysts in that study luteinized following treatment, but did not ovulate.

When the cysts which were present at ovariectomy in this study were viewed histologically, they consisted of three different types, based on the appearance of the theca as follows: (1) those with 
apparent luteinization; (2) those which were structurally similar to large atretic follicles, but without apparent luteinization or connective tissue; and (3) those infiltrated with connective tissue. Serum concentrations of progesterone in cows exhibiting cysts with luteinized theca remained below $2 \cdot 0 \mathrm{ng} / \mathrm{ml}$ for the experimental period. These levels are below those expected for cows exhibiting luteinized cysts after GnRH treatment (Kesler et al., 1981; Hernandez-Ledezma et al., 1982). The cysts observed in the present study were not luteinized to the extent that luteinization was visually apparent. It was not until histological observations were made that the three classes of cysts became apparent.

From these results, it is clear that the cystic condition is dynamic in nature. Based upon changes in concentrations of hormones in serum, follicular turnover in cows with follicles remaining cystic may be accompanied by increases in serum concentration of oestradiol-17 $\beta$. Since ovaries were not palpated per rectum after cyst marking, it was not determined whether increases of oestradiol-17 $\beta$ paralleled follicular development and turnover. Based upon the hormonal changes detected, it was difficult to establish why certain cows (only 3 in this study) display a single follicular cyst, which has the ability to persist, while in most cows there is a turnover of cysts, or why some cows spontaneously recover from the cystic condition.

In summary, follicular cysts in cattle are not static structures. They regress and are replaced with other cystic structures. The turnover in some cows is characterized by ovulation of a new follicle at a site different than the original cyst. Whether or not the turnover rate and growth of follicles in cows with cysts is similar to that observed in cows exhibiting normal oestrous cycles is unknown.

Contribution from the Missouri Agricultural Experiment Station Journal Series No. 10,943 and Regional Research Project, NC-113, Methods for Improvement of Fertility in Cows Postpartum. This research was supported in part by U.S.D.A. Grant, USDA-86-CRCR-1-2137.

We thank Greg Haley, Beth Feldkamp and Amos Morris for time and effort in assisting with the collection of samples and assistance with assays; Gary Bremar for technical assistance in preparing the histological sections of the ovaries; Sheila Ardrey for her assistance in the typing of this manuscript; G. D. Niswender for supplying antiserum to LH; the National Hormone and Pituitary Program for supplying iodination preparation and antiserum to FSH; and D. J. Bolt for supplying the reference preparation of bovine FSH.

\section{References}

Al-Dahash, S.Y.A. \& David, J.S.E. (1977) Anatomical features of cystic ovaries in cattle found during an abattoir survey. Vet. Rec. 101, 320-324.

Bierschwal, C.J., Garverick, H.A., Martin, C.E., Youngquist, R.S., Cantley, T.C. \& Brown, M.D. (1975) Clinical response of dairy cows with ovarian cysts following treatment with GnRH. J. Anim. Sci. 41, 1660-1665.

Brown, E.M., Elmore, R.G., Garverick, H.A. \& Kesler, D.J. (1982) Gonadotropin releasing hormone treatment of dairy cows with ovarian cysts. II. Histology of ovarian cyst walls. Theriogenology 17, 689-696.

Cantley, T.C., Garverick, H.A., Bierschwal, C.J., Martin, C.E. \& Youngquist, R.S. (1975) Hormonal response of dairy cows with ovarian cysts following treatment with GnRH. J. Anim. Sci. 41, 1666-1673.

Choudary, J.B., Gier, H.T. \& Marion, G.B. (1968) Cyclic changes in bovine vesicular follicles. J. Anim. Sci. 27, $468-471$.

Dufour, J., Whitmore, H.L., Ginther, O.J. \& Casida, L.E. (1972) Identification of the ovulating follicle by its size on different days of the estrous cycle in heifers. $J$. Anim. Sci. 34, 85-87.

Erb, R.E., Monk, E.L., Callahan, C.J. \& Mollett, T.A. (1973) Endocrinology of induced ovarian follicular cysts. J. Anim. Sci. 37 (Suppl. 1), 310, abstr.

Garm, O. (1949) A study of bovine nymphomania. Acta Endocr., Copenh., Suppl. 3, 1-144.

Garverick, H.A., Kesler, D.J., Cantley, T.C., Elmore, R.G., Youngquist, R.S. \& Bierschwal, C.J. (1976) Hormone response of dairy cows with ovarian cysts after treatment with hCG or GnRH. Theriogenology 6, 413-420.

Garverick, H.A., Parfet, J.R., Lee, C.N., Copelin, J.P., Youngquist, R.S. \& Smith, M.F. 1988) Relationship of pre- and post-ovulatory gonadotropin concentrations to subnormal luteal function in postpartum beef cattle. J. Anim. Sci. 66, 104-111.

Gill, J.L. \& Hafs, H.D. (1971) Analysis of repeated measurements of animals. J. Anim. Sci. 33, 331-336.

Hernandez-Ledezma, J.J. Garverick, H.A., Elmore, R.G., Brown, E.M. \& Kesler, D.J. (1982) Gonadotropin

Downloaded from Bioscientifica.com at 04/26/2023 07:55:05AM via free access 
releasing hormone treatment of dairy cows with ovarian cysts. III. Steroids in ovarian follicular fluid and ovarian cyst fluid. Theriogenology 17, 697-707.

Ireland, J.J. (1987) Control of follicular growth and development. J. Reprod. Fert., Suppl. 34, 39-54.

Kesler, D.J. \& Garverick, H.A. (1982) Ovarian cysts in dairy cattle: A review. J. Anim. Sci. 55, 1147-1159.

Kesler, D.J., Garverick, H.A., Caudle, A.B. Bierschwal, C.J., Elmore, R.G. \& Youngquist, R.S. (1978) Clinical and endocrine responses of dairy cows with ovarian cysts to GnRH and/or $\mathrm{PGF}_{2} \alpha$. J. Anim. Sci. 46, $719-725$.

Kesler, D.J., Garverick, H.A., Caudle, A.B., Elmore, R.G., Youngquist, R.S. \& Bierschwal, C.J. (1980) Reproductive hormone and ovarian changes in cows with ovarian cysts. J. Dairy $S c i .63,166-170$.

Kesler, D.J., Elmore, R.H., Brown, E.M. \& Garverick, H.A. (1981) Gonadotropin releasing hormone treatment of dairy cows with ovarian cysts. I. Gross ovarian morphology and endocrinology. Theriogenology 16, 207-216.

Marion, G.B., Gier, H.T. \& Choudary, J.B. (1968) Micromorphology of the bovine ovarian follicular system. J. Anim. Sci. 27, 451-465.

Matton, P., Adelakoun, V., Couture, Y. \& Dufour, J.J. (1981) Growth and replacement of the bovine ovarian follicles during the estrous cycle. J. Anim. Sci. 52, $8 \mathrm{I} 3-820$.

Pierson, R.A. \& Ginther, O.J. (1987) Follicular populations during the estrous cycle in heifers. I. Influence of day. Anim. Reprod. Sci. 14, 165-176.

Priedkalns, J., Weber, A.F. \& Zemjanis, R. (1968) Qualitative and quantitative morphological studies of the cells of the membrana granulosa, theca interna and corpus luteum of the bovine ovary. Z. Zellforsch. mikrosk. Anat. 85, 501-520.

Rajakowski, E. (1960) The ovarian follicular system in sexually mature heifers with special reference to seasonal, cyclical and left-right variations. Acta endocr., Copenh., Suppl. 52, 1-68.
SAS (1985) SAS User's Guide: Statistics, Version 5 Edition. Statistical Analysis System Institute Inc., Cary, NC.

Savio, J.D., Keenan, L., Boland, M.P. \& Roche, J.F. (1988) Pattern of growth of dominant follicles during the oestrous cycle in heifers. J. Reprod. Fert. 83, $663-671$

Short, R.V. (1962) Steroid concentrations in normal follicular fluid and ovarian cyst fiuid from cows. $J$. Reprod. Fert. 4, 27-45.

Sirois, J. \& Fortune, J.E. (1988) Ovarian follicular dynamics during the estrous cycle in heifers monitored by real-time ultrasonography. Biol. Reprod. 39, $308-317$

Snedecor, G.W. \& Cochran, W.C. (1980) Statistical Methods, 7th edn, pp. 288-292. The Iowa State University Press, Ames.

Swanson, L.V., Hafs, H.D. \& Morrow, D.A. (1972) Ovarian characteristics and serum LH, prolactin, progesterone and glucocorticoid from first estrus to breeding size in Holstein heifers. J. Anim. Sci. 34, 284-293.

Winters, T.A., Cook, D.L. Callahan, C.J. \& Allrich, R.D. (1986) Induction of ovarian cysts in cattle by injections of progesterone and estradiol-17ß.J. Anim. Sci. 63 (Suppl. 1); 361, abstr.

Yamauchi, M. \& Inui, S. (1954) Studies on the ovarian cyst in the cow. II. Endocrinological and histological studies on the correlation between the ovarian cyst and the symptom of the cows. Japanese J. vet. Sci. 16, 27-36.

Zaied, A.A., Garverick, H.A., Bierschwal, C.J., Elmore, R.G., Youngquist, R.S. \& Sharp, A.J. (1980) Effect of ovarian activity and endogenous reproductive hormones on GnRH-induced ovarian cycles in postpartum dairy cows. J. Anim. Sci. 50, 508-513.

Received 3 October 1989 